\title{
Congenital Deficiency of Growth Hormone and Prolactin
}

Ichiro Miyata, Nobuhiko Sasaki and Yoshikatsu Eto

Department of Pediatrics, The Jikei University School of Medicine, Tokyo, Japan

Abstract The case is presented of a 25-year-old woman with congenital deficiency of growth hormone (GH) and prolactin (PRL). Her height was $108 \mathrm{~cm}$ (-9.98 standard deviation (SD)) on admission. She had a bulging forehead and a small nose with a retracted bridge. Basal levels of GH and PRL were low. In stimulation tests of GH secretion, no responses were observed. In a thyrotropinreleasing hormone (TRH) loading test, the response of PRL was poor but that of thyrotropin (TSH) was normal. The levels of other pituitary hormones were normal. magnetic resonance imaging (MRI) of the brain revealed no abnormalities. In examination of the pituitary-specific transcription factor (Pit-1/GHF-1)(Pit-1) gene in this patient by the polymerase chain reaction-single-strand conformation polymorphism (PCR-SSCP) and deoxy ribonucleic acid (DNA) sequencing analysis, neither mutations nor deletions were detected.

Keywords: Pit-1, combined pituitary hormone deficiency, growth hormone, prolactin

\section{Introduction}

Congenital combined pituitary hormone deficiencies are rare and their causes are unknown. In 1992 a nonsense mutation in the Pit-1 gene, which is a pituitary transcription factor for GH and PRL genes, was first detected in a case of combined pituitary hormone deficiency (CPHD) for GH, PRL and TSH, by Tatsumi et al (1). More than ten cases with abnormalities in the Pit-1 gene have been reported since then (2-4). Recently, the concept of "Pit-1 abnormality" has been established as a new clinical manifestation of CPHD for GH,

Received: September 12, 1994

Accepted: February 7, 1995

Correspondence: Dr.Ichiro Miyata, Department of Pediatrics, The Jikei

University School of Medicine, 3-25-8 Nishi-shinbashi, Minato-ku, Tokyo 105 Japan
PRL and TSH.

We present the a case of a 25-year-old woman with congenital CPHD for GH and PRL, and describe the analysis of her Pit- 1 gene.

\section{Case Report}

The patient was a 25-year-old woman who had been born normally at term. At birth her length was $49 \mathrm{~cm}$ and weight was 2,950 g. Her early development was poor and at the age of 3 she was shorter than her brother who was two years younger. At the age of 16 her height was $105.7 \mathrm{~cm}$ (-10.1 SD). Menarche occurred at the age of 12 and she has regular menses. In her family there was no one with extreme short stature and no consanguinity was recognized.

In 1990 she was admitted for investiga- 
Miyata et al.

tion. She was $108 \mathrm{~cm}(-9.98 \mathrm{SD})$ tall and her weight was $22 \mathrm{~kg}$. Her pubertal development was Tanner stage V, and the epiphyseal lines were closed. A bulging forehead and a small nose with retracted bridge were recognized (Fig. 1). Her mental ability was normal.

Results of routine blood examinations and urinalysis were normal. Endocrinological data were as follows; peak serum levels of GH after stimulation with insulin and glucagon-propranolol were $0.6 \mathrm{ng} / \mathrm{mL}$ and $0.5 \mathrm{ng} / \mathrm{mL}$, respectively. The serum insulin-like growth factor I (IGF-I) was less than $0.14 \mathrm{U} / \mathrm{mL}$. The serum $3,5,3$ '-triiodothyronine ( $\left.\mathrm{T}_{3}\right)$ was $80 \mathrm{ng} / \mathrm{dL}$, and

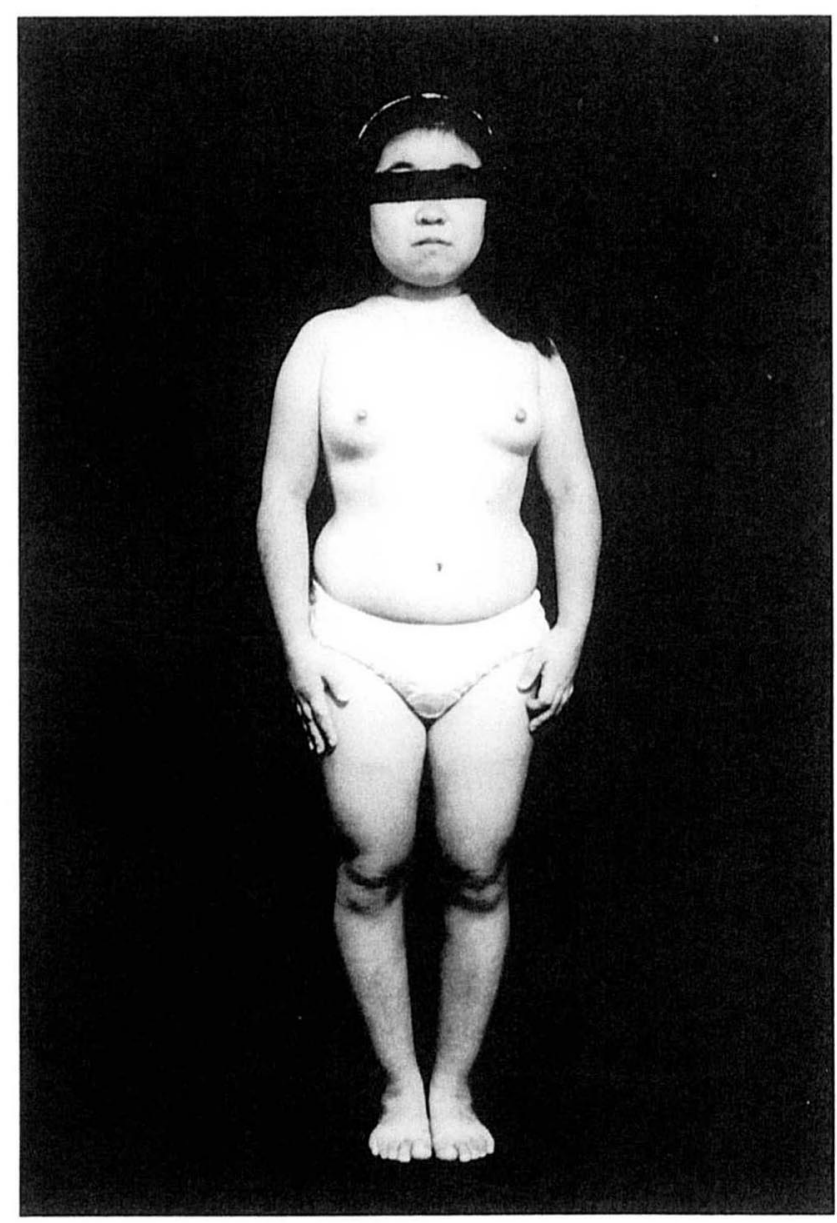

Fig. 1 Appearance of patient the serum thyroxine $\left(\mathrm{T}_{4}\right)$ was $6.0 \mu \mathrm{g} / \mathrm{dL}$. The TSH level was $2.0 \mu \mathrm{U} / \mathrm{mL}$, and the PRL was less than $1.0 \mathrm{ng} / \mathrm{mL}$. Although the response of

Table 1 Endocrinological date on admission

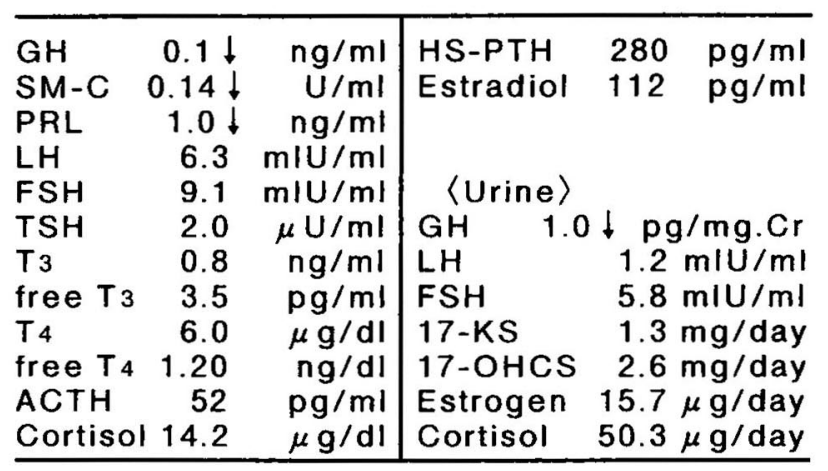

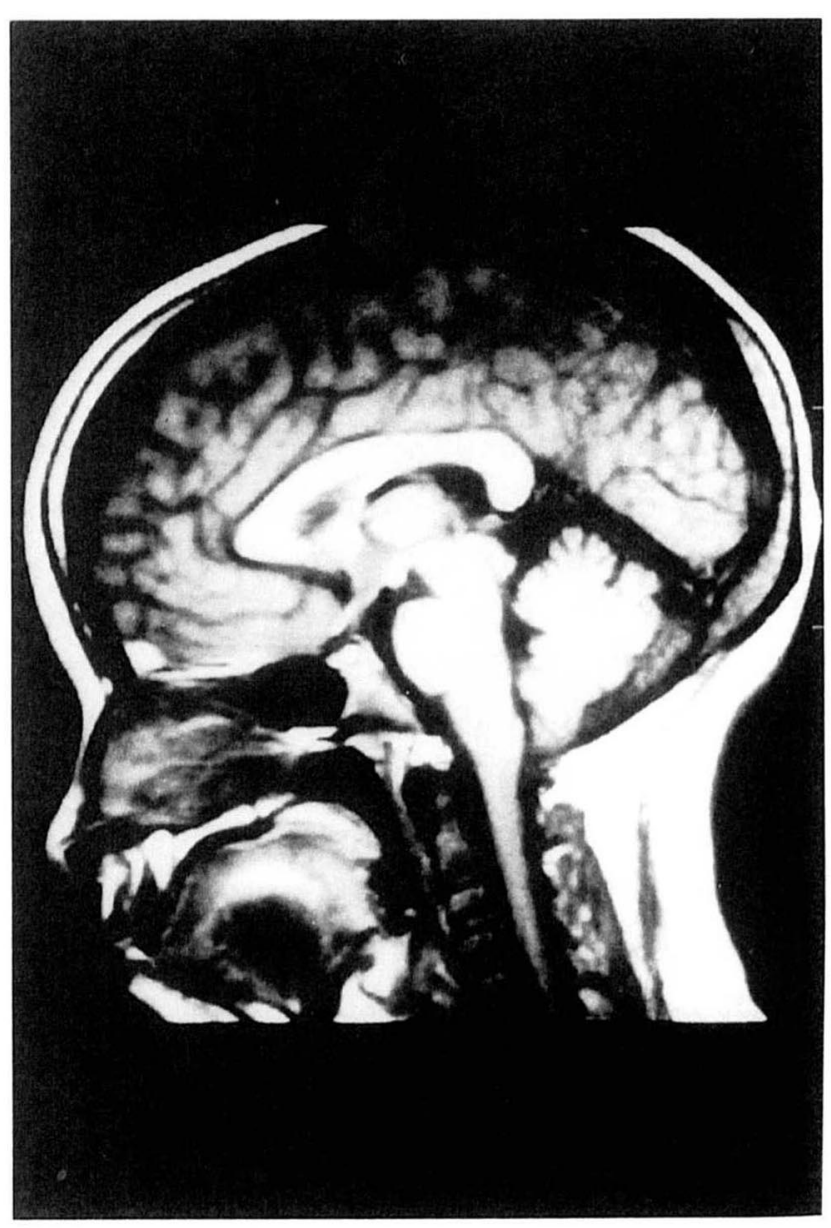

Fig. 2 MRI of the brain (T1-weighted sagital image) 


\section{Congenital Deficiency of GH and PRL}

Table 2 Endocrinological studies

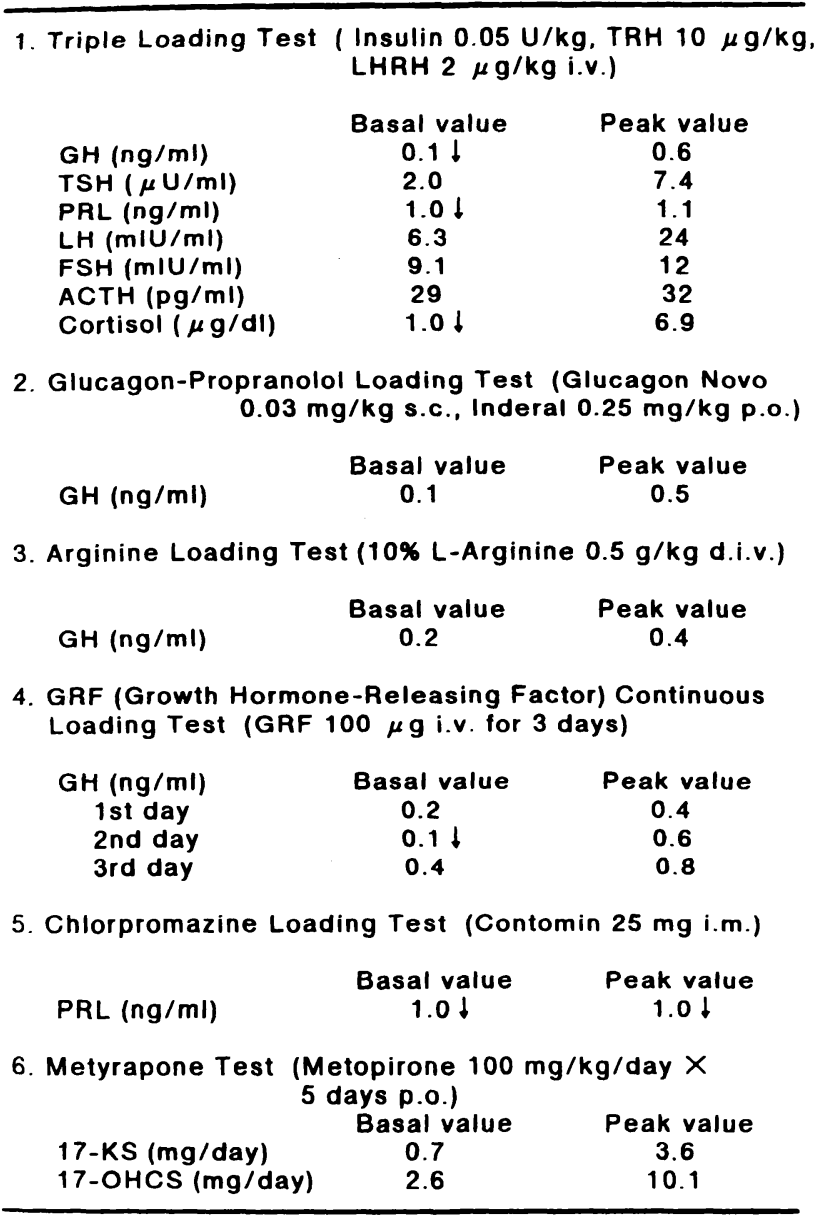

serum TSH in a TRH loading test was normal, the peak PRL was $1.1 \mathrm{ng} / \mathrm{mL}$ and no response was recognized. In a luteinizing hormonereleasing hormone (LHRH) loading test, the levels of luteinizing hormone (LH) and folliclestimulating hormone (FSH) showed normal responses. Moreover, the responses of urine 17ketosteroids and 17-hydroxycorticosteroid in a metyrapone test were also normal (Table 1, 2). MRI of the brain revealed no abnormality of the pituitary gland (Fig. 2). On the basis of these results, congenital CPHD for GH and PRL, was diagnosed.

\section{Genetic Analysis}

\section{Preparation of DNA}

High-molecular-weight genomic DNA was extracted from white blood cells of our patient and from controls as previously described (5), and the concentration of DNA in each sample was determined by measuring the optical density of each solution of purified DNA at $260 \mathrm{~nm}$.

\section{PCR-SSCP analysis}

A set of six pairs of primers was prepared, based on the sequence of the Pit- 1 gene: for exon 1, 5'-AT CGGCCCTTTGAGACAGTAA3'/5'-CCCGGTCATATGTAAACTG-3'; for exon 2, 5'-TTTCTCGGTGACAACGTTG-3'/5'GTGTCCCCAAATTCAATAAC-3'; for exon 3, 5'-AAGGAGAATGACAAATGGTC-3'/5'AAGTTCTTTTTCCTGTTGCC-3'; for exon 4, 5'-AAAGTTGGAGCTGATGGTC-3'/5'CACAGCCTTCAGAGACAC-3'; for exon 5, 5'TTTGTAATTATCTCTCTTTTCC-3'/5'TACACTCAAATGCTCATTCC-3'; and for exon 6, 5'-AATTTCACCCCCTATGTCC-3'/5'GAAACGGGAGAAAAAGGCT-3'. These primers were designed to amplify regions that covered each exon and the exon-intron boundaries (Fig. 3). The exons of genomic DNA (0.4 $\mu \mathrm{g})$ from the patient and controls were amplified by the polymerase chain reaction (PCR) using these specific primers and were scanned

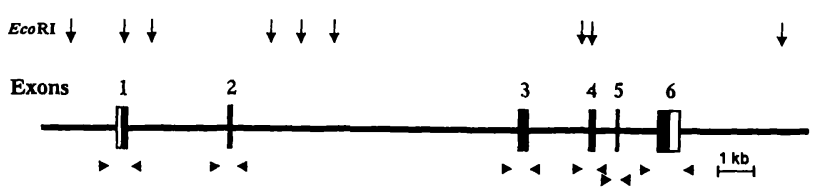

Fig. 3 Structure of the human gene for Pit-1 


\section{Miyata et al.}

for mutations or deletions by established techniques for detection of single-strand conformation polymorphism (SSCP)(6). For SSCP, the reaction volume was $50 \mu \mathrm{L}$ and the reaction mixture included $1 \mu \mathrm{Ci}$ of $\alpha^{-32} \mathrm{P}$-labelled dCTP (ICN). The conditions for PCR were as follows: initial denaturation for $6 \mathrm{~min}$ at $94^{\circ} \mathrm{C}$; then 30 cycles of denaturation at $94{ }^{\circ} \mathrm{C}$ for 30 second, annealing at $55{ }^{\circ} \mathrm{C}$ for $1 \mathrm{~min}$, and extension at $75^{\circ} \mathrm{C}$ for $1 \mathrm{~min}$; final extension at $75^{\circ} \mathrm{C}$ for 10 min. Fragments were separated on a $40-\mathrm{cm} 5$ $\%$ polyacrylamide $(24: 1)$ gel run in $0.5 \times$ Trisborate buffer at room temperature with 5 $\%$ glycerol. The gel was run at 40 watts for 3 hours and was then exposed to X-ray film overnight.

\section{DNA sequencing analysis}

For sequencing, a reaction volume of 100 $\mu \mathrm{L}$ was used and the conditions for PCR were

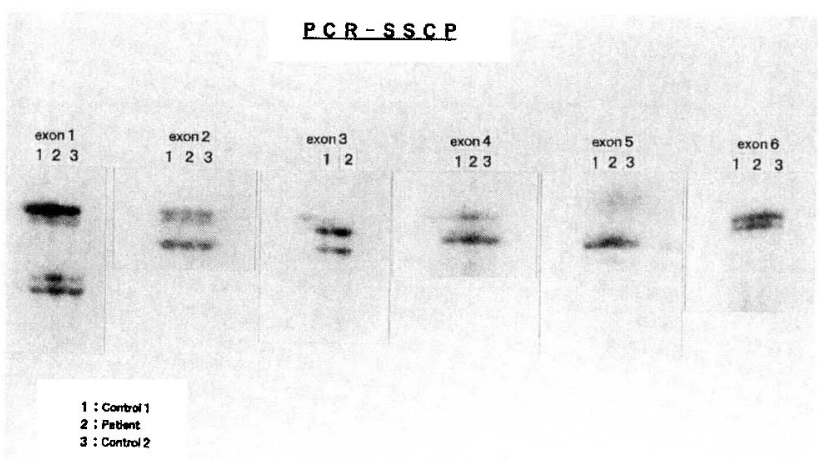

Fig. 4 PCR-SSCP analysis. None of the exons showed differences in mobility between the patient and controls

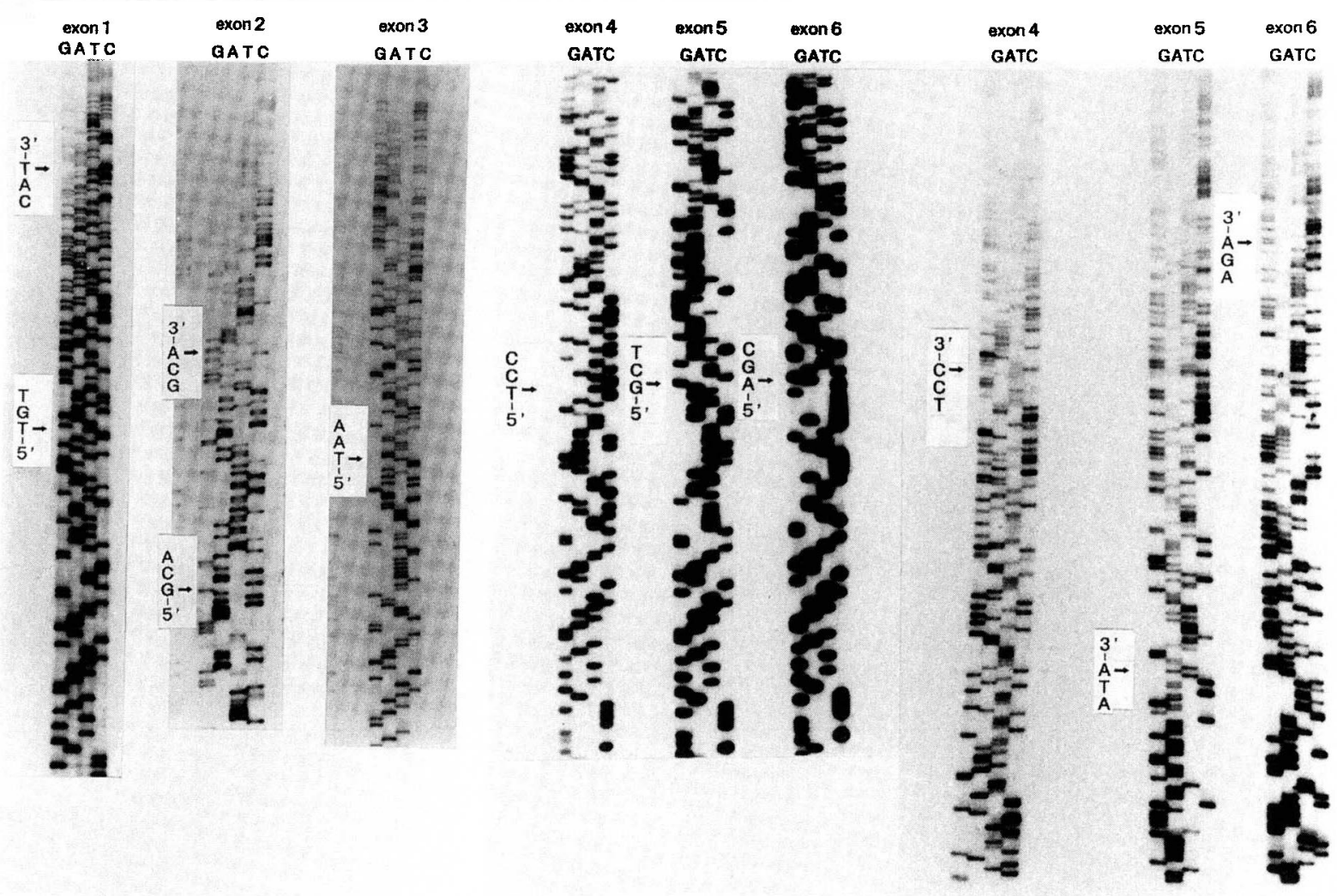

Fig. 5 DNA sequence analysis of the patient. The DNA sequence of each exon is normal. Neither mutations nor deletions can be recognized 


\section{Congenital Deficiency of GH and PRL}

the same as described above. After PCR, the specific amplified genomic exons of the patient were subcloned and used for transformation using a TA-cloning kit (Invitrogen). Five independent clones were sequenced by the dideoxy chain-termination method for each exon.

Results of PCR-SSCP analysis of each exon are shown in Fig. 4. The mobilities of single-stranded DNA fragments from the patient were not significantly different from those from controls.

Results of DNA sequencing analysis are shown in Fig. 5. The DNA sequence of each exon from the patient was normal. Neither mutations nor deletions were recognized.

\section{Discussion}

A Japanese patient with CPHD for GH, PRL and TSH was first reported by Yoshimoto et $a l$, in 1990 (7). The patient had extreme short stature (-8.7 SD), a bulging forehead and a small nose with retracted bridge, which are characteristically seen in patients with familial isolated growth hormone deficiency (IGHD) type IA (8-9). Psychomotor development was normal. MRI of the brain revealed hypoplasia of the anterior pituitary gland. Although genetic analysis by Southern blot was performed, no deletions were recognized in the GH and PRL genes, and it was thought that the cause might be due to mutations in the Pit-1 gene.

Pit-1 is a pituitary-specific transcription factor that binds to and transactivates promoters of the genes for GH and PRL (10-13). Pit-1 contains two protein domains, termed the POU-specific and POU-homeodomains, both of which are necessary for high-affinity binding to DNA of the genes for GH and PRL. Pit- 1 is also important for the control of transcription of the gene that encodes the $\beta$ subunit of thyrotropin (TSH- $\beta$ ) by TRH and cyclic adenosine 3',5'monophosphate (14-16).

In 1990, mutations in the Pit-1 gene were identified in two strains of mice, $d w$ and $d w^{J}$, with CPHD for GH, PRL and TSH (17). Homozygosity for these mutations results in severe hypoplasia of the anterior pituitary gland, with the absence of somatotropes, lactotropes and thyrotropes. In humans, a nonsense mutation in the POU-specific DNA-binding domain of the Pit-1 gene was detected in a case of familial CPHD for GH, PRL and TSH by Tatsumi et al, in 1992 (1). As a consequence, the concept of "Pit-1 abnormality" has been established as a new clinical manifestation of CPHD. In 1992 Pfaffle et al, reported two Dutch patients with Pit-1 abnormality with a mutation in the Pit-1 gene that changed an alanine residue in the first putative $\alpha$-helix of the POU-specific domain to a proline residue. In these cases, GH and PRL were absent, but TSH was present at detectable levels (3). Thus it has been considered that Pit-1 abnormality exhibits varying the degrees of deficiency for $\mathrm{GH}, \mathrm{PRL}$ and TSH. However, an abnormality in the Pit-1 gene has not yet been reported in congenital CPHD that involves only GH and PRL.

Our patient with congenital CPHD for GH and PRL had no TSH deficiency, and MRI of the brain showed a normal pituitary gland. With regard to these clinical features, it seems that this patient is different from the Pit-1 abnormality previously reported. To examine the Pit-1 gene PCR-SSCP and DNA sequencing analysis were performed but no abnormalities in the structural gene were found. These results are consistent with three posibilities for 
the cause of CPHD for GH and PRL in cases such as ours. First, CPHD for GH and PRL might be due to abnormal splicing of Pit-1 messenger ribonucleic acid (mRNA). Second, it might be due to an abnormality in an unidentified gene other than Pit-1. Recently, abnormalities in the mechanism that regulates transcription of the Pit-1 gene have been proposed in mice with CPHD for GH and PRL. In such mice, the Pit-1 gene is normal. Third, it is possible that no genetic defect is associated with this disease.

Congenital CPHD for GH and PRL is a rare disease. Further studies will be required to determine whether abnormalities in the Pit1 gene can be identified in other patients with CPHD for GH and PRL.

\section{Acknowledgment}

The authors thank Keita Tatsumi, MD, Department of Laboratory Medicine, Osaka University Medical School, for his helpful advice and supplying the specific primers for PCR.

\section{References}

1. Tatsumi K, Miyai K, Notomi T, Kaibe K, Amino N, Mizuno Y, et al. Cretinism with combined hormone deficiency caused by a mutation in the PIT1 gene. Nat Genet 1992; 1: 56-8.

2. Radovick S, Nations M, Du Y, Berg LA, Weintraub BD, Wondisford FE. A mutations in the POU-homeodomain of Pit-1 responsible for combined pituitary hormone deficiency. Science 1992; 257:1115-8.

3. Pfaffle RW, DiMattia GE, Parks JS, Brown MR, Wit JM, Jansen M, et al. Mutation of the POU-specific domain of Pit-1 and hypopituitarism without pituitary hypoplasia. Science 1992; 257:1118-21.

4. Ohta $\mathrm{K}$, Nobukuni $\mathrm{Y}$, Mitsubuchi $\mathrm{H}$, Fujimoto S, Matsuo N, Inagaki $\mathrm{H}$, et al. Mutations in the Pit-1 gene in children with combined pituitary hormone deficiency. Biochem Biophys Res Commun 1992; 189: 851-5.

5. Kunkel LM, Smith KD, Boyer SH, Borgaonkar DS, Wachtel SS, Miller OJ, et al. Analysis of human Y-chromosome-specific reiterated DNA in chromosome variants. Proc Natl Acad Sci USA 1977; 74: 1245-9.

6. Orita $M$, Iwahana $H$, Kanazawa $H$, Hayashi K, Sekiya T. Detection of polymorphisms of human DNA by gel electrophoresis as single-strand conformation polymorphisms. Proc Natl Acad Sci USA 1989; 86: 2766-70.

7. Yoshimoto M, Kinoshita E, Baba $\mathrm{T}$, Matsumoto T, Nii-kawa N, Matsuda I, et al. A case of severe pituitary dwarfism associated with prolactin and thyroid stimulating hormone deficiencies. Acta Pædiatr Scand 1990; 79: 1247-51.

8. Illig R. Growth hormone antibodies in patients treated with different preparations of human growth hormone (hGH). J Clin Endocrinol Metab 1970; 31: 679-88.

9. Phillips JA III, Hjelle BL, Seeburg PH, Zachmann M. Molecular basis for familial isolated growth hormone deficiency. Proc Natl Acad Sci USA 1981; 78: 6372-5.

10. Bodner M, Castrillo JL, Theill LE, Deerinck T, Ellisman M, Karin M. The pituitary-specific transcription factor GHF1 is a homeobox-containing protein. Cell 


\section{Congenital Deficiency of GH and PRL}

1988; 55: 505-18.

11. Ingraham HA, Chen $R$, Mangalam $H J$, Elsholtz HP, Flynn SE, Lin CR, et al. A tissue-specific transcription factor containing a homeodomain specifies a pituitary phenotype. Cell 1988; 55: 519-29.

12. Nelson C, Albert VR, Elsholtz HP, Lu LIW, Rosenfeld MG. Activation of cell-specific expression of rat growth hormone and prolactin genes by a common transcription factor. Science 1988; 239:1400-5.

13. Theill LE, Castrillo JL, Wu D, Karin M. Dissection of functional domains of the pituitary-specific transcription factor GHF1. Nature $1989 ; 342: 945-8$

14. Day RN, Maurer RA. Mol. The distal enhancer region of the rat prolactin gene contains elements conferring response to multiple hormones. Endocrinology 1989; 3: 3-9. Steinfelder HJ, Hauser P, Nakayama Y,
15. Radovick S, McClaskey JH, Taylor T, et al. Thyrotropin-releasing hormone regulation of human TSHB expression: role of a pituitary-specific transcription factor (Pit1/GHF-1) and potential interaction with a thyroid hormone-inhibitory element. Proc Natl Acad Sci USA 1991; 88: 3130-4.

16. Steinfelder HJ, Radovick S, Mroczynski MA, Hauser P, McClaskey JH, Weintraub $\mathrm{BD}$, et al. Role of a pituitary-specific transcription factor (Pit-1/GHF-1) or a closely related protein in cAMP regulation of human thyrotropin-beta subunit gene expression. J Clin Invest 1992; 89: 409-19.

17. Li S, Crenshaw III EB, Rawson EJ, Simmons DM, Swanson LW, Rosenfeld MG. Dwarf locus mutants lacking three pituitary cell types result from mutations in the POU-domain gene Pit-1. Nature 1990; 347: 528-33. 